\title{
Organic Functionalization of Mesoporous Silica Spheres as a Nanovehicle for DOX pH-Triggered Delivery
}

\author{
Shuai Wang*, Fang Xiang Song ${ }^{\dagger}$, Li Zhang ${ }^{\dagger}$, Xue Zhang* and Yan Li*§ \\ *School of Pharmacy \\ Guizhou University \\ Guiyang 550025, P. R. China \\ ${ }^{\dagger}$ School of Chemistry and Chemical Engineering \\ Guizhou University \\ Guiyang 550025, P. R. China \\ *Guiyang Vocational and Technical College \\ Guiyang 550025, P. R. China \\ $\S_{y a n l i @ g z u . e d u . c n}$
}

Received 1 March 2019

Accepted 11 June 2019

Published 1 August 2019

\begin{abstract}
Mesoporous silica (MS) spheres of different sizes with $\mathrm{pH}$-responsive characteristics were synthesized based on Stöber's theory. Organic functionalization with aminopropyl and carboxyl groups resulted in different materials, namely, $\mathrm{MS} @ \mathrm{NH}_{2} @ \mathrm{COOH} . \mathrm{MS}_{2} \mathrm{NH}_{2} @ \mathrm{COOH}$ were observed to have a large number of carboxyl groups and multiamine chains, and were grafted into pore channels and pore outlets through systematic characterization analyses. All modified samples demonstrated the controlling of the delivery rate of DOX from the siliceous matrix. We also compared the drug release behavior of the DOX-loaded materials at high $\mathrm{pH}(7.4)$ and low $\mathrm{pH}$ (5.5) and studied the cytotoxicity on A549 cells. The experimental results indicated that the drug delivery system can better control drug release and have potential applications in the drug delivery field.
\end{abstract}

Keywords: Mesoporous silica spheres; different sizes; organic functionalization; drug delivery.

\section{Introduction}

The application of nanovehicles for drug delivery has attracted increased attention in recent years due to their advantageous structural properties, such as nanoliposomes ${ }^{1}$ and electrospun fibers, ${ }^{2,3}$ which are widely used as drug delivery vehicles. In addition, mesoporous materials are another type of nanoparticles that have been widely used for drug $\S_{\text {Corresponding author. }}$ delivery. Mesoporous materials have a large specific surface area and pore volume, as well as a tunable pore structure. Surface chemical modification that uses active sites or physical adsorption through directional modification can achieve the ideal effect of new functional materials, ${ }^{4-12}$ particularly mesoporous silica (MS) materials. ${ }^{13,14}$ The physical, chemical, and structural properties of MS are controlled 
by changing the experimental conditions and reactant ratio. In 2001, Kresge et al. ${ }^{15}$ discovered a series of M41S MS materials. MS has potential research applications in the field of medicine. The particle size of MS can reach the nanoscale, which can withstand thermal and mechanical stresses as well as $\mathrm{pH}$ and oxidation degradation, with low toxicity and good biocompatibility. ${ }^{16-19}$ These characteristics enable us to change the drug-loading capacity by adjusting the pore diameter through surface modification to achieve the controlled and targeted release of drugs. ${ }^{20} \mathrm{MS}$ has the following remarkable characteristics $^{21-24}$ : (1) an ordered pore network, (2) a large pore volume, (3) a large specific surface area, and (4) a large amount of $\mathrm{Si}-\mathrm{OH}$ on the surface. These unique features make MS an excellent alternative to drug delivery carrier materials. ${ }^{25,26}$ Organic groups ${ }^{27-31}$ can be grafted onto the surface of mesoporous materials through modification or functionalization. Although these organic functional groups can ensure the good adsorption of drugs, such as common model drugs aspirin ${ }^{32,33}$ and DOX,${ }^{34}$ their loading capacity is low and the loading takes a long time. ${ }^{35-38}$ For instance, Feng et al. ${ }^{34}$ developed a targeted anticancer drug delivery system based on folate-conjugated nanospheres modified with boron nitride (BNNS-FA). However, the DOX loading capacity of the BNNS and BNNS-FA complexes was calculated only to be $6.9 \mu \mathrm{g}$ and $20.7 \mu \mathrm{g}$ per $1 \mathrm{mg}$ of carriers, respectively, which is lower than ours. Adhikari et $a .^{35}$ developed a drug delivery system that takes $72 \mathrm{~h}$ to load drug molecules.

To overcome the aforementioned shortcomings, the number of functional groups should be increased to increase the number of activity sites. Martinez et $a l .{ }^{39}$ used a polyamine chain silane coupling agent to modify the surface of MS and obtain a functional material with the "switch effect." At a high $\mathrm{pH}$, polyamine chains are close to each other
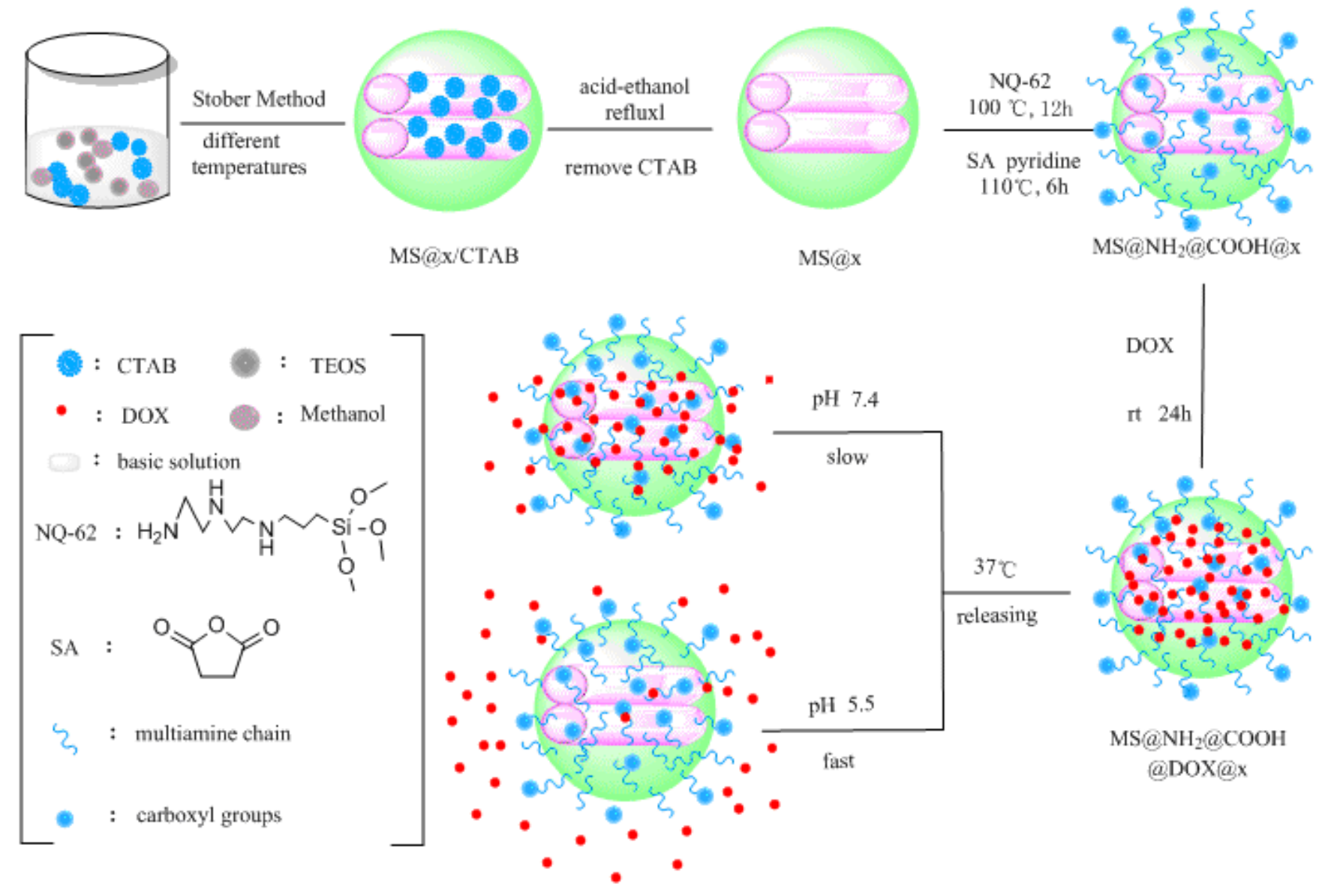

Scheme 1. Schematic illustration of the synthesis strategy of organic functionalization of MS and its working principle as a pH-responsive drug carrier. 
(the "closed" state) due to the interaction of hydrogen bonds. At a low $\mathrm{pH}$, polyamine chains are protonated and Coulombic repulsion occurs among ammonium groups (the "opened" state).

These pioneering works grafted organic molecules before removing the template agent, which made organic molecules "switchable gates" on pore outlets. The current study introduces a reverse method, in which the organic groups were grafted after removing the template agent. This study is based on previous experimental research on DOX as a model drug, following Stöber's theory ${ }^{40}$ of the synthesis of MS in a water-methanol-ammonium hydroxideTEOS system at different temperatures. We obtained MS spheres with diameters ranging from 80 to $290 \mathrm{~nm}$ and explored the effects of different physical and chemical characteristics on drug loading and the release of mesoporous nanoparticles. 3[2-(2-aminoethylamino)ethylamino]propyl-trimethoxysilane(NQ-62) and succinic anhydride (SA) were utilized as modifying agents in organic functionalization processing. We carried out drug-loading and releasing experiments and studied the cytotoxicity on A549 cells as well. Scheme 1 shows the synthetic strategies and the working principle.

\section{Experimental}

\subsection{Reagents}

Tetraethyl orthosilicate (TEOS; AR, Tianjin, China), cetyltrimethylammonium bromide (CTAB; AR, Tianjin, China), hydrochloric acid ( $\mathrm{HCl}$, 36-38\%, Chongqin, China), ammonia solution $\left(\mathrm{NH}_{3} \cdot \mathrm{H}_{2} \mathrm{O}\right.$; AR, Chengdu, China $)$, 3-[2-(2-aminoethylamino)ethylamino]propyl-trimethoxy silane (NQ-62, 95\%; Shanghai, China), ethanol and methanol (EtOH, MeOH; AR, Tianjin, China), succinic anhydride (SA, 99\%, Aladdin, Shanghai), phosphate-buffered saline (PBS; pH 5.5 and $\mathrm{pH}$ 7.4), and DOX were purchased from Aladdin (Shanghai, China) and used without further purification. All the water used was deionized.

\subsection{Preparation of the samples}

The one-step procedure proposed was used to synthesize mesoporous silica. This study applied Stöber's theory. The water-methanol-ammonium hydroxide-TEOS system was used to synthesize MS in a basic environment (the $\mathrm{pH}$ value was adjusted to 11.24 for $300 \mathrm{~mL}$ of a water-methanol mixed solution $(v / v=11 / 4)$ with ammonium hydroxide (25-28\% $\mathrm{NH}_{3}$ in water)): $0.58 \mathrm{~g}$ of CTAB was added at a rotating speed of $1200 \mathrm{rpm}$. Then $4.65 \mathrm{~g}$ of TEOS was added dropwise (at a molar ratio of $\mathrm{H}_{2} \mathrm{O}$ : $\mathrm{CH}_{3} \mathrm{OH}: \mathrm{CTAB}$ :TEOS equal to 545:88.5:0.07096:1), stirred for $3 \mathrm{~h}$, and aged for another $3 \mathrm{~h}$. The procedure was performed to synthesize MS at different temperatures. The synthesized MS was filtered and washed several times with water/ethanol to obtain a white solid, which was air-dried and then ovendried at $80^{\circ} \mathrm{C}$ for $24 \mathrm{~h}$. To generate the mesoporous structure of the silica nanoparticles, the materials were extracted with acid-ethanol and finally called MS@x $(x=40,50$ and 80, denoting the temperatures at which the MS was obtained: $40^{\circ} \mathrm{C}, 50^{\circ} \mathrm{C}$ and $80^{\circ} \mathrm{C}$ ).

\subsection{Amination and carboxylation of the samples}

MS@x were organically modified using the postgrafting method. Briefly, 500 mg MS@x was evenly dispersed in $40 \mathrm{~mL}$ dry toluene and bath sonicated for $30 \mathrm{~min}$. Then, $1.5 \mathrm{~mL}$ of NQ-62 was added, the mixture was stirred for $12 \mathrm{~h}$ at $100^{\circ} \mathrm{C}$, and the resulting solid was isolated and washed with dry toluene. The resulting solid was dried under a vacuum at $60^{\circ}$. The substance was called $\mathrm{MS} @ \mathrm{NH}_{2} @ \mathrm{x}$.

Five hundred milligrams of $\mathrm{MS}_{\mathrm{NH}} @ \mathrm{x}$ was dispersed into $50 \mathrm{~mL}$ pyridine solution and stirred for $1 \mathrm{~h}$ at room temperature. Then, $4.5 \mathrm{~g}$ of SA was added and the mixture was stirred for $6 \mathrm{~h}$ at $110^{\circ} \mathrm{C}$; the resulting solid was isolated and washed with water and ethanol. The resulting solid was then dried under a vacuum at $35^{\circ}$. The substance was called $\mathrm{MS} @ \mathrm{NH}_{2} @ \mathrm{COOH} @ \mathrm{x}$.

\subsection{Release and storage of drug}

First, $50 \mathrm{mg}$ of DOX was dissolved in a mixture of $28.5 \mathrm{~mL}$ deionized water and $1.5 \mathrm{~mL}$ PBS buffer. Then, $100 \mathrm{mg}$ solid adsorbent was dispersed in this solution, and the mixture was stirred at room temperature in the dark for $24 \mathrm{~h}$ at a stirring speed of $500 \mathrm{rpm}$, centrifuged at $8000 \mathrm{rpm}$ for $4 \mathrm{~min}$ and washed twice with deionized water to obtain DOX-loaded solid sorbents, namely, $\mathrm{MS} @ \mathrm{NH}_{2} @$ COOH@DOX@x and MS@DOX@x. The solid was dried under a vacuum at $35^{\circ}$. To measure the loading amount of DOX, $1 \mathrm{~mL}$ supernatant was diluted in $25 \mathrm{~mL}$ fluid. UV-6100s was used for 
wavelength analysis under $480 \mathrm{~nm}$. Parallel measurement was conducted thrice, and the average result was obtained via the following formula ${ }^{41}$ :

$$
w t \%=\left[\frac{m_{1}-C V}{m_{2}+m_{1}}\right] \times 100 \%,
$$

where $m_{1}$ is the initial mass of DOX;

$m_{2}$ is the mesoporous adsorbent added into hexane solution;

$C$ is the DOX concentration of the supernatant solution;

$V$ is the volume of the supernatant solution.

In the release experiment, each sample was immersed in two kinds of PBS buffer solution, i.e., $\mathrm{pH}$ 5.5 and $\mathrm{pH}$ 7.4. Then, $15 \mathrm{mg}$ of different DOXloaded solid sorbents was placed in dialysis bags, the molecular weights of which ranged from 8000 to 14000 Da. Afterwards, $100 \mathrm{~mL}$ of $\mathrm{pH} 5.5$ or pH 7.4 PBS was added into a $100 \mathrm{~mL}$ flask and stirred at $37^{\circ} \mathrm{C}$ at a rate of $100 \mathrm{rpm}$. Subsequently, $3 \mathrm{~mL}$ PBS with different $\mathrm{pH}$ values was added into the dialysis bags. Simultaneously, $3 \mathrm{~mL}$ of fluid was taken out and $3 \mathrm{~mL}$ fresh PBS was immediately added into the flask. UV-6100 was used for wavelength detection absorbance under $480 \mathrm{~nm}$. The accumulated concentration was calculated for each moment:

$$
C_{c}=C_{t}+\frac{v}{V} \sum_{0}^{t-1} C_{t},
$$

where $C_{c}$ is the real concentration of DOX released at time $t$;

$C_{t}$ is the apparent concentration measured by UV-Vis spectrometry of the release fluid sample at time $t$;

$\nu$ is the volume of sample taken at the predetermined time intervals;

$V$ is the total volume of release fluid.

\subsection{Cell cytotoxicity assay}

The cytotoxicity of MS@x, MS@NH $\mathrm{NH}_{2} \mathrm{COOH} @ \mathrm{x}$ and $\mathrm{MS} @ \mathrm{NH}_{2} @ \mathrm{COOH} @ \mathrm{DOX} @ \mathrm{x}$ was evaluated by MTT assay on A549 cells. The A549 cells were grown in standard conditions of $5 \% \mathrm{CO}_{2}$ at $37^{\circ} \mathrm{C}$. In brief, A549 cells were seeded in 96-well plates at a density of $2 \times 10^{4}$ cells per well. DOX, MS@x,

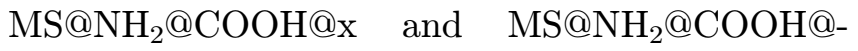
DOX@x with various concentrations were coincubated with A549 cells for $24 \mathrm{~h}$. The cells were then washed with PBS, and $100 \mu \mathrm{L}$ of MTT solution
$(0.5 \mathrm{mg} / \mathrm{mL})$ was slowly injected into each well and incubated for $4 \mathrm{~h}$. Absorbance was detected by a microplate reader, and the cell viability of the variously treated groups was calculated. A plot of concentration versus cell viability (\%) was drawn:

$$
\text { Cell viability }(\%)=\frac{\mathrm{OD}_{\text {sample }}}{\mathrm{OD}_{\text {control }}} \times 100 \% \text {, }
$$

where $\mathrm{OD}_{\text {sample }}$ is the absorbance value of the sample group;

where $\mathrm{OD}_{\text {control }}$ is the absorbance value of the control group.

\subsection{Characterization}

The powder X-ray diffraction (XRD) patterns were recorded using a Rigaku D/Max 2400 diffractometer with a $\mathrm{Cu}$ Ka radiation. Fourier transform infrared (FTIR) spectra were obtained with a Nicolet iS50 spectrophotometer using $\mathrm{KBr}$ pellets. The Brunauer-Emmett-Teller (BET) surface area and average pore volume of the synthesized MS materials were measured by a Micromeritics ASAP 2020 analyzer at $77 \mathrm{~K}$. Transmission electron microscopy (TEM) images of the samples were taken using a FEI G20 electron microscope operating at $200 \mathrm{kV}$. The morphological features of the samples were investigated by scanning electron microscopy (SEM) on a JEOL-JSM-7500F electron microscope operating at $20 \mathrm{kV}$, coupled with an EDS micro-analyzer. UV absorbance spectra were obtained with a Mapada UV-6100s spectrophotometer. Thermogravimetric analysis (TGA-DTA/DSC) was conducted in air on an STA 449C Jupiter ${ }^{\circledR}$ thermal analyzer. The samples were heated from $30^{\circ} \mathrm{C}$ to $1000^{\circ} \mathrm{C}$ at a heating rate of $10^{\circ} \mathrm{C} / \mathrm{min}$ in air.

\section{Results and Discussion}

\subsection{Structural characteristics of the sample}

Figures 1(a)-1(c) show the XRD patterns of MS@x, $\mathrm{MS} @ \mathrm{NH}_{2} @ \mathrm{x}$ and $\mathrm{MS} @ \mathrm{NH}_{2} @ \mathrm{COOH} @ \mathrm{x}$. An evident (100) peak can be observed for all the samples in Fig. 1(a), which indicates that they are ordered mesoporous structures. ${ }^{42-44}$ In Figs. 1(b) and 1(c), the apparent (100) peaks disappeared except for the $40^{\circ} \mathrm{C}$ materials, which may be due to the larger pore size. This means that the pore structure changed from an ordered mesoporous structure to a 


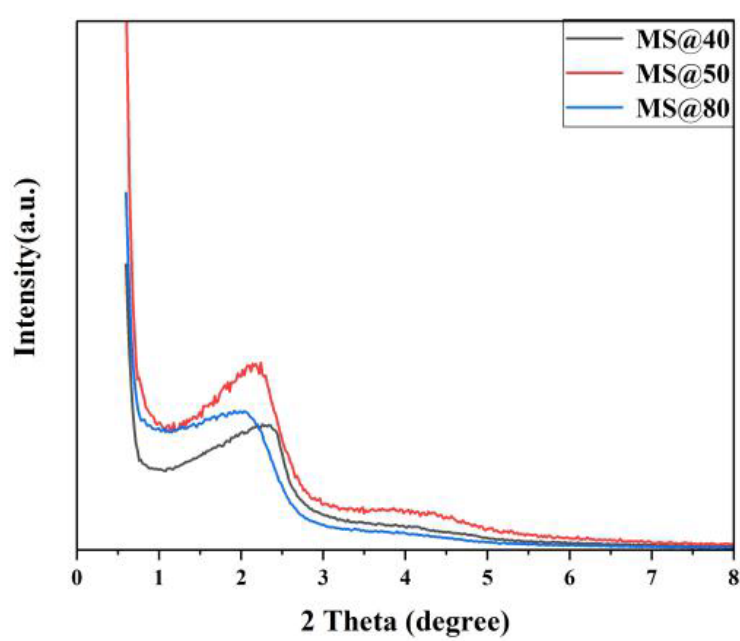

(a)

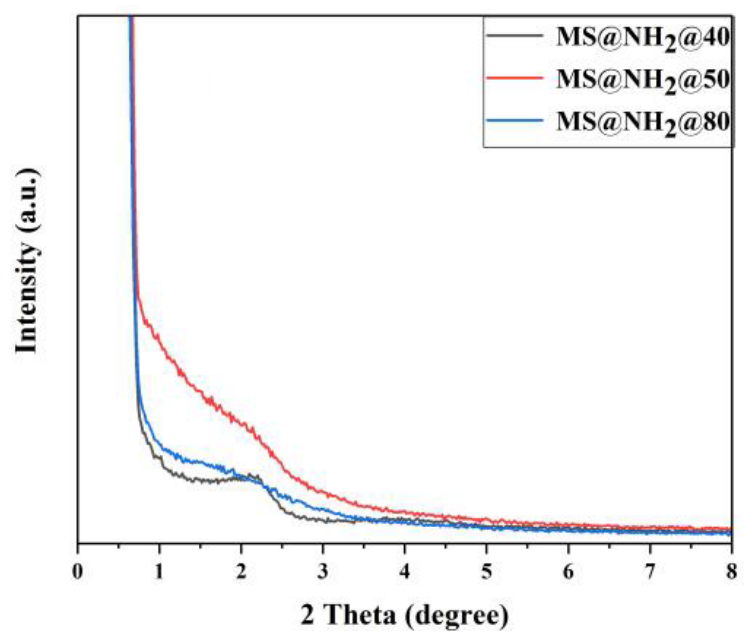

(b)

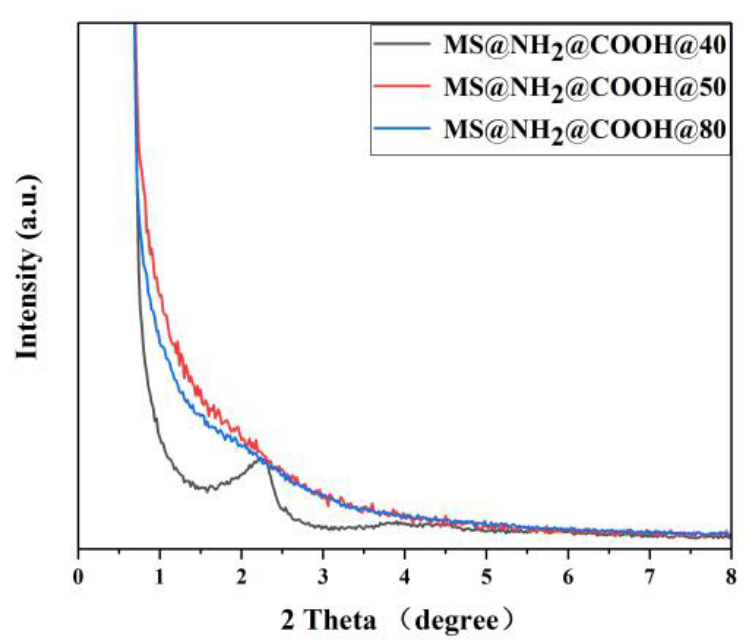

(c)

Fig. 1. XRD patterns of the MS@x (a), MS@NH $\mathrm{N}_{2} @ \mathrm{x}(\mathrm{b})$ and $\mathrm{MS} @ \mathrm{NH}_{2} @ \mathrm{COOH} @ \mathrm{x}(\mathrm{c})$ samples. disordered mesoporous channel, indicating that the organic groups have been implanted into the pore channels or pore outlets of mesoporous silica.

In theory, these grafted organic groups should divide into two mesoporous parts, i.e., one part around the pore outlets and one part into the pore channels. The relative values of the $d$ space initially increased and then decreased, which indicated that the introduction of organic groups exerted a significant destructive influence resulting from the condensation between silanol and the organic groups during the modification process and a significant effect on the $d$ space value of the mesoporous structure.

Figures 2 and 3 show the SEM, particle size distribution, EDS and TEM images of the MS@40, MS@50 and MS@80 samples. All the samples are spherical, indicating that the change in temperature has no influence on the morphology of the materials. Figure 2 shows that their average particles measured $107 \pm 6,136 \pm 14$ and $268 \pm 13 \mathrm{~nm}$, which shows that the diameter gradually increases with the increase in temperature, the size becomes uniform and the reunion phenomenon gradually disappears [Figs. 2(a)-2(c)]. The elemental composition of these materials, assessed by X-ray energydispersive spectroscopy [EDS; Figs. 2(d)-2(f)], indicated the successful modification of amino and carboxyl. Figures 3(a)-3(c) show that the dispersity and uniformity of MS@40 and MS@50 are poor, whereas those of MS@80 are good. Notably, MS@x, with an ideal sphere structure and open framework structure, should be beneficial for the uniform distribution of modified groups around, inside and outside the pores.

Figures 4(a)-4(c) show the adsorption/desorption isotherm and the distribution of pore size and pore volume of the $\mathrm{MS} @ \mathrm{x}, \mathrm{MS} @ \mathrm{NH}_{2} @ \mathrm{x}$ and $\mathrm{MS} @ \mathrm{NH}_{2} @ \mathrm{COOH} @ \mathrm{x}$ samples. All samples present a typical type IV adsorption isotherm, which indicates the presence of mesoporous channels, and the MS@40, MS@50 and MS@80 samples exhibit the characteristics of $\mathrm{H} 1$ type IV materials. The appearance of the $\mathrm{H} 1$ hysteresis loop on the adsorption isotherm indicates its relatively high pore size uniformity and facile pore connectivity. $\mathrm{MS} @ \mathrm{NH}_{2} @ 50$ is a type IV material with $\mathrm{H} 4$ hysteresis loop characteristics, whereas $\mathrm{MS} @ \mathrm{NH}_{2} @ 40$, $\mathrm{MS} @ \mathrm{NH}_{2} @ \mathrm{COOH} @ 40, \quad \mathrm{MS}_{4} \mathrm{NH}_{2} @ \mathrm{COOH} @ 50$, $\mathrm{MS} @ \mathrm{NH}_{2} @ 80$ and $\mathrm{MS} @ \mathrm{NH}_{2} @ \mathrm{COOH} @ 80$ are type IV materials with $\mathrm{H}_{3}$ hysteresis loop characteristics. 

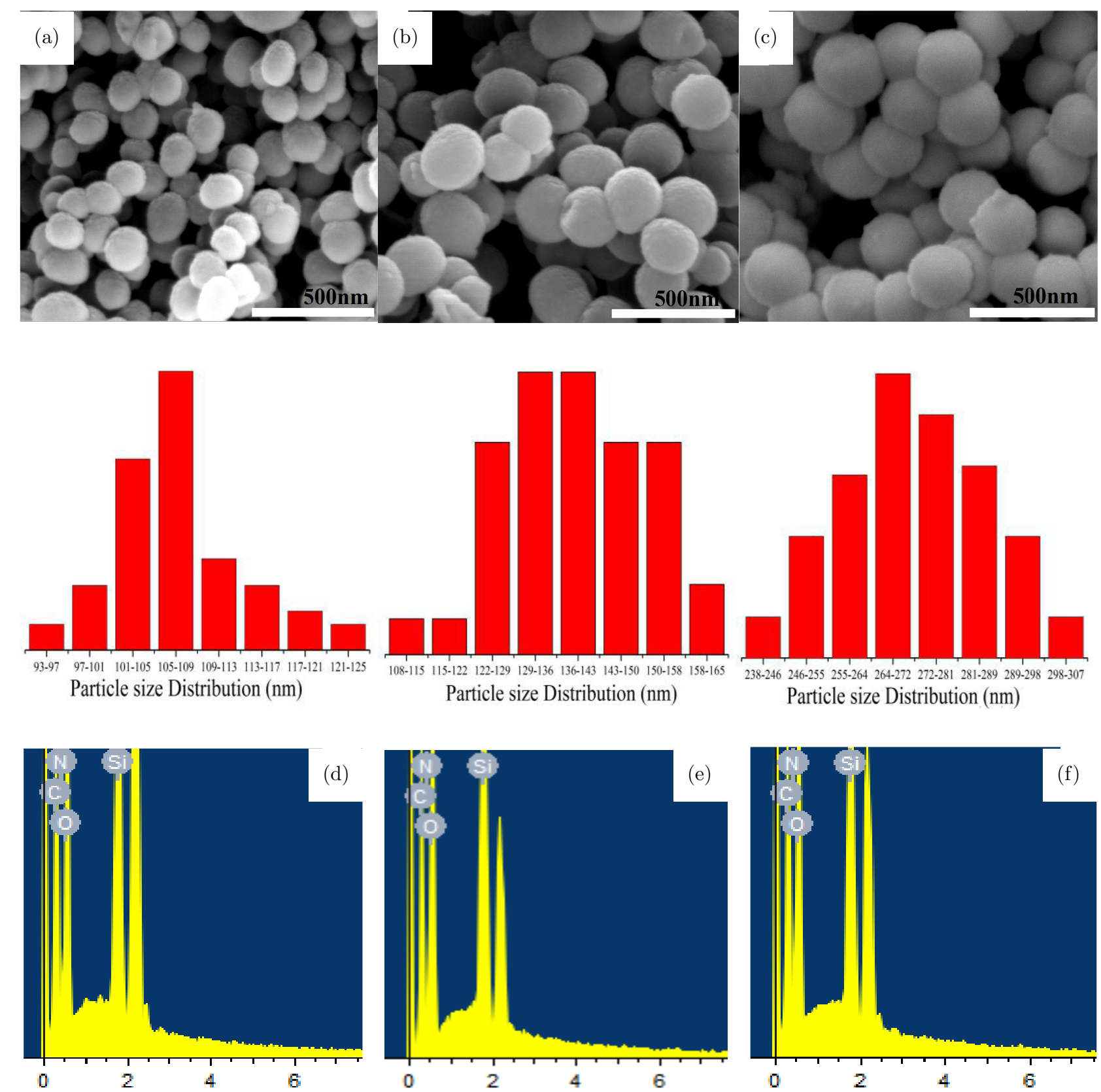

Fig. 2. SEM (top), particle size distribution (middle) and EDS (bottom) images of the MS@40, MS@50 and MS@80 samples.

The type H3 hysteresis loop may have contributed to the narrow slit-like pores due to a successful grafting of organic groups around the pore outlet and the inner pore wall. A type $\mathrm{H} 4$ hysteresis loop may arise from the presence of large mesopores embedded in a matrix with pores of much smaller size. ${ }^{45}$

The hysteresis loop indicates that the materials have no evidently saturated adsorption platform. Moreover, the pore structure is not uniform, reflecting the tablet slit structure or fractured structure. ${ }^{41}$ In a low-pressure area, the amount of adsorption of the MS@40, MS@50 and MS@80 materials exhibits an increased linear process, which explains why the test material has a mesoporous structure.

The corresponding pore size distribution plots and pore volume were calculated using the BarrettJoyner-Halenda (BJH) method, ${ }^{46}$ and the specific surface area was calculated using the BET method (Table 1). The pore diameter, pore volume and specific surface area of all the samples decreased, 

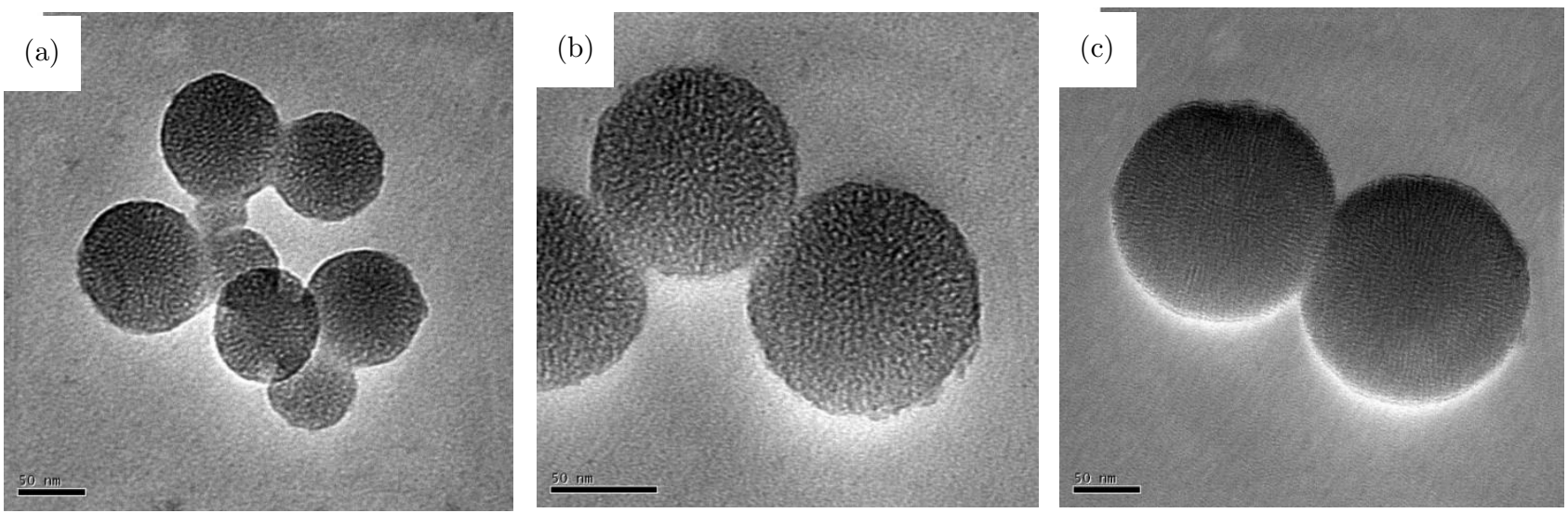

Fig. 3. TEM images: (a) MS@40, (b) MS@50 and (c) MS@80 samples.

indicating that organic groups are grafted onto the pore wall of the mesoporous material. The decrease in specific surface area was due to the presence of pendant organic chains covalently bonded to the inorganic network, which have the ability to partially block the entrance of nitrogen molecules, indicating that organic groups were fastened inside mesopores. From the previously presented analysis, the following conclusions can be drawn. (1) Under the condition of changing temperature, the pore size, pore volume and specific surface area of the materials have changed. (2) After organic functionalization, pore size, specific surface area and pore volume decrease. (3) The organic groups are grafted into the pore outlet and pore wall of the mesoporous material.

The samples were further characterized by Fourier-transform infrared spectroscopy (FT-IR).

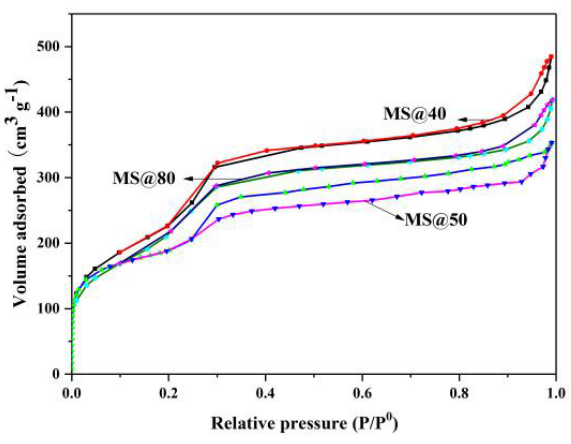

(a)

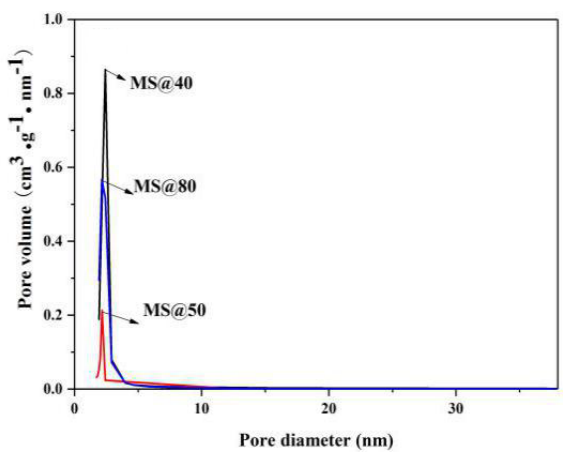

(d)

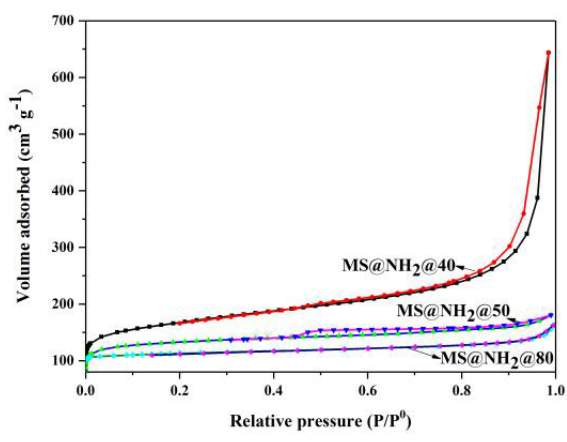

(b)

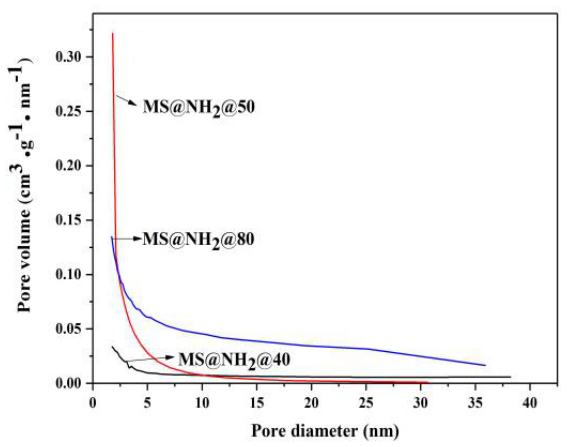

(e)

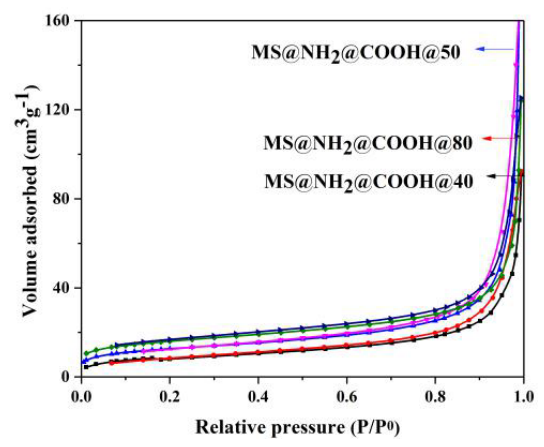

(c)

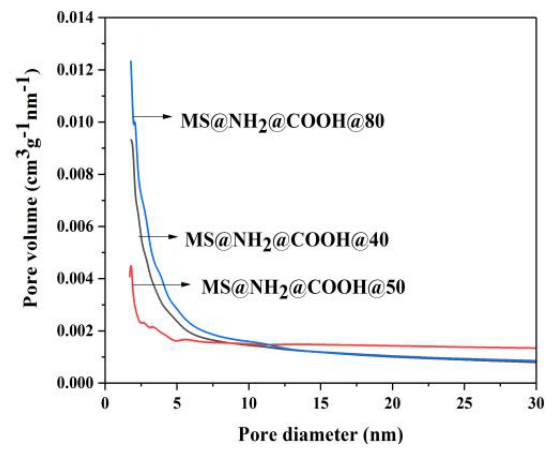

(f)

Fig. 4. $\mathrm{N}_{2}$ adsorption/desorption isotherms and the corresponding pore diameter distributions of $\mathrm{MS} @ \mathrm{x}, \mathrm{MS} @ \mathrm{NH} \mathrm{H}_{2} \mathrm{x}$ and $\mathrm{MS} @ \mathrm{NH}_{2} @ \mathrm{COOH} @ \mathrm{x}$. 


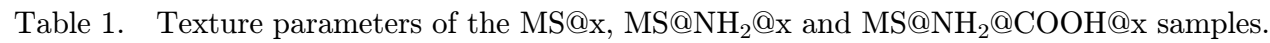

\begin{tabular}{lccc}
\hline Sample & $\begin{array}{c}\text { Specific surface area } \\
\left(S_{\mathrm{BET}}\right)\left(\mathrm{m}^{2} \mathrm{~g}^{-1}\right)\end{array}$ & $\begin{array}{c}\text { Pore volume } \\
\left(V_{p}\right)\left(\mathrm{cm}^{3} \mathrm{~g}^{-1}\right)\end{array}$ & $\begin{array}{c}\text { BJH adsorption pore } \\
\text { diameter }(\mathrm{nm})\end{array}$ \\
\hline $\mathrm{MS} 940$ & 987.79 & 0.75 & 2.42 \\
$\mathrm{MS} @ \mathrm{NH}_{2} @ 40$ & 569.58 & 0.034 & 1.77 \\
$\mathrm{MS} @ \mathrm{NH}_{2} @ \mathrm{COOH} 40$ & 32.56 & 0.004 & 1.74 \\
$\mathrm{MS} @ 50$ & 673.43 & 0.41 & 2.15 \\
$\mathrm{MS} @ \mathrm{NH}_{2} @ 50$ & 443.56 & 0.32 & 1.77 \\
$\mathrm{MS} @ \mathrm{NH}_{2} @ \mathrm{COOH} @ 50$ & 31.62 & 0.004 & 1.71 \\
$\mathrm{MS} @ 80$ & 915.27 & 0.65 & 2.14 \\
$\mathrm{MS} @ \mathrm{NH}_{2} @ 80$ & 549.817 & 0.134 & 1.74 \\
$\mathrm{MS} @ \mathrm{NH}_{2} @ \mathrm{COOH} @ 80$ & 37.62 & 0.012 & 1.74 \\
\hline
\end{tabular}

As shown in Fig. 5(A), stretching vibration peaks of the $-\mathrm{CH}_{2}$ of surfactant $\mathrm{CTAB}$ were observed at $2810 \mathrm{~cm}^{-1}$ and $2930 \mathrm{~cm}^{-1}$ in the FT-IR spectrum of $\mathrm{MS} @ \mathrm{x} / \mathrm{CTAB}$, whereas they were not found in MS@x, indicating that the template agent is nearly removed. In Fig. 5(B), the stretching vibration peaks of $\mathrm{Si}-\mathrm{O}-\mathrm{Si}$ appeared at $1078 \mathrm{~cm}^{-1}$ and $1230 \mathrm{~cm}^{-1}$, asymmetry vibration peaks were observed at $807 \mathrm{~cm}^{-1}$ and the band at $1471 \mathrm{~cm}^{-1}$ is the shear vibration peak of $-\mathrm{CH}_{2}$. Si-OH has a symmetrical stretching vibration peak at $954 \mathrm{~cm}^{-1}$. In addition, the bands at $1592 \mathrm{~cm}^{-1}$ are attributed to the stretching vibration peaks of $\mathrm{N}-\mathrm{H}$ and the bands at $1705 \mathrm{~cm}^{-1}$ can be assigned to the absorption peaks of $\mathrm{COOH}$, indicating the successful modification of amino and carboxyl, respectively. The characteristic peak of benzene of DOX

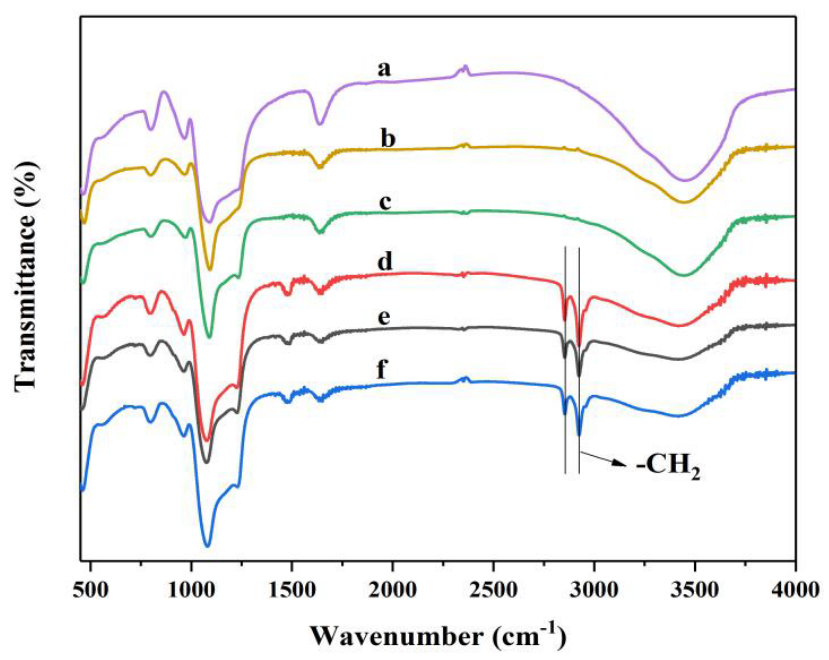

(A) molecules can be clearly observed at 1430$1600 \mathrm{~cm}^{-1}$, and a new characteristic peak appears at $1398-1595 \mathrm{~cm}^{-1}$, indicating the presence of DOX in the mesoporous channels. After loading DOX, however, the carboxyl and amine group form the secondary amide. ${ }^{47,48}$ Thus, new characteristic peaks ${ }^{49}$ appear at $1630-1680 \mathrm{~cm}^{-1}$ (amide I belt) as the carbonyl stretching vibration peak and at 1560 $1512 \mathrm{~cm}^{-1}$ (amide II belt) as the $\mathrm{N}-\mathrm{H}$ deformation vibration peak.

Figures 6(a) and 6(b) show the TGA curves of the materials. All the samples exhibited mass loss centered at $30-100^{\circ} \mathrm{C}$ because water was physically sorbed onto the surface. ${ }^{50,51} \mathrm{MS} @ \mathrm{x} /$ CTAB exhibited weight loss that could be attributed to the disintegration of the surfactant CTAB [Fig. 6(a)], but not at $200-600^{\circ} \mathrm{C}$, indicating that

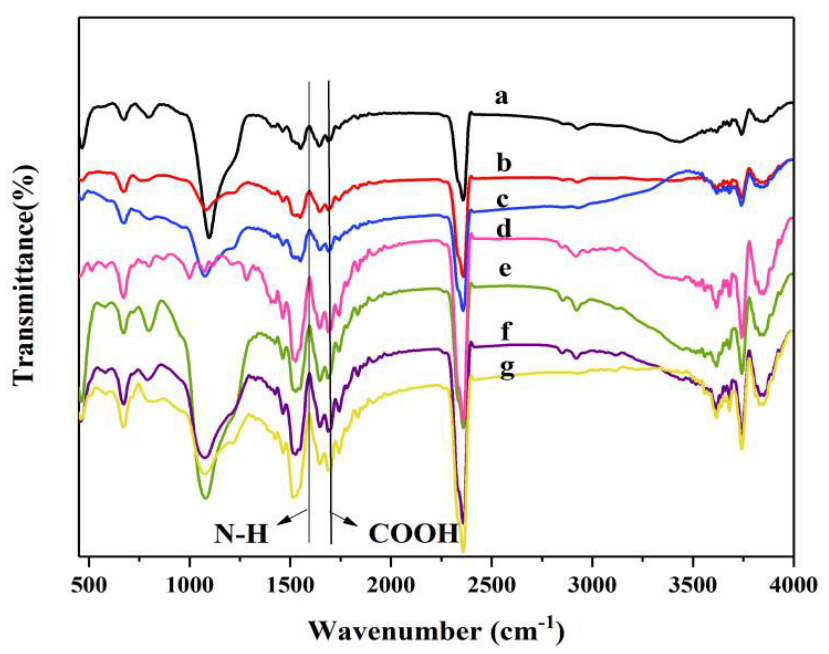

(B)

Fig. 5. (A) Infrared spectrum of MS@x/CTAB and MS@x. (B) FTIR spectra of: (a) MS@NH $@$ COOH@40; (b)

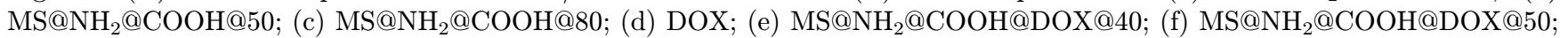
(g) $\mathrm{MS} @ \mathrm{NH}_{2} @ \mathrm{COOH} @ \mathrm{DOX} @ 80$. 


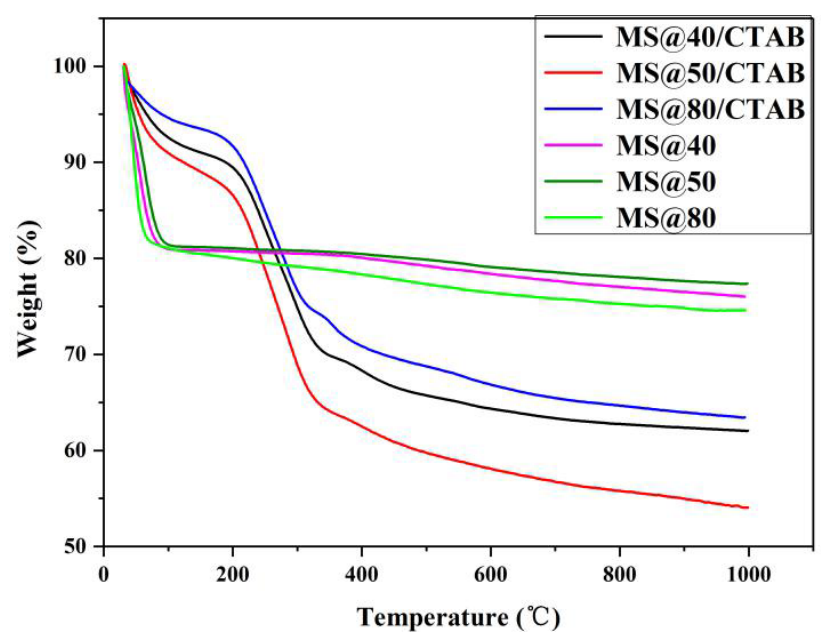

(a)

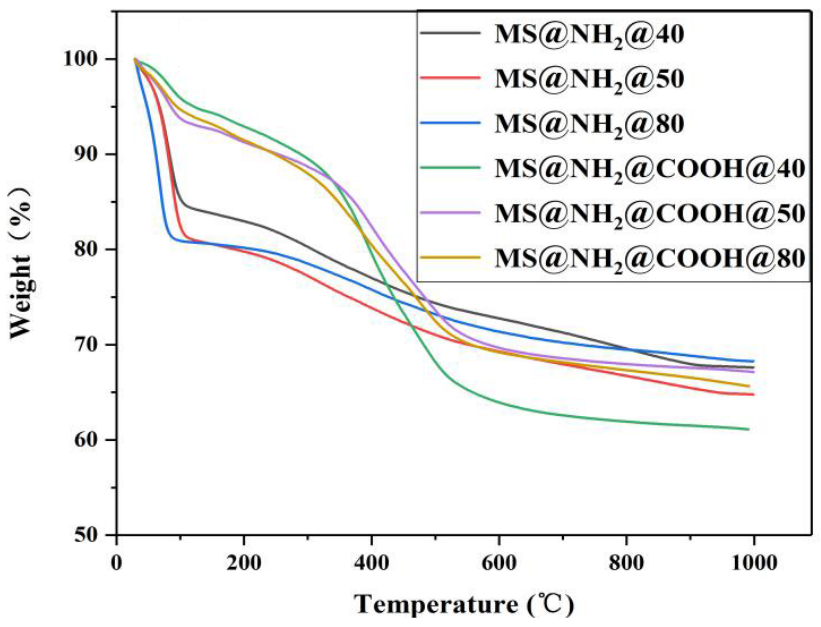

(b)

Fig. 6. TGA curves of MS@x/CTAB, MS@x, MS@NH $\mathrm{N}_{2} @ \mathrm{x}$ and $\mathrm{MS} @ \mathrm{NH}_{2} @ \mathrm{COOH} @ \mathrm{x}$.

the surfactant CTAB was completely removed. Meanwhile, for the MS@NH${ }_{2} @ \mathrm{x}$ samples, the TGA curves exhibited weight loss at $100-500^{\circ} \mathrm{C}$, which was due to the removal of multiamine groups. Figure 6(b) shows the thermogram of MS@$\mathrm{NH}_{2} @ \mathrm{COOH} @ \mathrm{x}$. There are two main decomposition processes: weight losses of $4.75 \%, 3.63 \%$ and $4.91 \%$ are observed at temperatures of $100-250^{\circ} \mathrm{C}$, which is attributed to the loss and degradation of the carboxyl groups. This was followed by weight losses of $26.72 \%, 19.53 \%$ and $20.43 \%$ between $230^{\circ} \mathrm{C}$ and $550^{\circ} \mathrm{C}$, originating from the successful attachment of a polyamine chain and the carboxyl group of the material. These findings are significant evidence of the existence of organic groups on the surface and inner pore of MSN@x. ${ }^{52}$

\subsection{In vitro cytotoxicity}

The cytotoxicity of $\mathrm{MS} @ \mathrm{x}, \mathrm{MS} @ \mathrm{NH}_{2} @ \mathrm{COOH} @ \mathrm{x}$, $\mathrm{MS} @ \mathrm{NH}_{2} @ \mathrm{COOH} @ D O X @ \mathrm{x}$ and free DOX was evaluated by an MTT assay on A549 cells. As Figs. 7(a)-7(c) shows, MS@x and $\mathrm{MS} @ \mathrm{NH}_{2} @-$ COOH@x exhibited minimal cytotoxicity to cells at concentrations ranging from 0.1 to $50 \mu \mathrm{g} \mathrm{mL}^{-1}$. Nearly $97.57 \%, 95.85 \%$ and $95.54 \%$ of the cells were alive at a maximum concentration of $50 \mu \mathrm{g} \mathrm{mL}^{-1}$ of MS@x. The concentration of DOX-loaded nanomaterials applied was lower than $50 \mu \mathrm{g} \mathrm{mL}^{-1}$ in the following experiments, so we could assume that the drug delivery vehicle had no obvious toxicity for A549 cells. Figure 7 exhibits the inhibited effects of three DOX-loaded samples ( $\mathrm{MS} @ \mathrm{NH}_{2} @ \mathrm{COOH} @ \mathrm{x}$,
$\mathrm{MS} @ \mathrm{NH}_{2} @ \mathrm{COOH} @ \mathrm{DOX} @ \mathrm{x}$ and free DOX) on A549 cells in a dose-dependent manner. Free DOX (the pink column in Fig. 7) showed a certain cytotoxicity to A549 cells whose cell viability was $5.08 \%$ at a concentration of $50 \mu \mathrm{g} \mathrm{mL}^{-1}$. The cell viability of $\mathrm{MS} @ \mathrm{NH}_{2} @ \mathrm{COOH} @ \mathrm{DOX} @ \mathrm{x}$ was found to be $7.93 \%, 6.29 \%$ and $9.71 \%$ at the corresponding synthesis temperatures of $40^{\circ}, 50^{\circ}$ and $80^{\circ}$, respectively. $\mathrm{MS} @ \mathrm{NH}_{2} @ \mathrm{COOH} @ \mathrm{DOX} @ 40$ presented the highest cell mortality of the three DOXloaded nanomaterials, and the values of $\mathrm{IC}_{50}$ are $3.125 \mu \mathrm{g} \mathrm{mL}^{-1}, 2.901 \mu \mathrm{g} \mathrm{mL}^{-1}$ and $5.315 \mu \mathrm{g} \mathrm{mL}^{-1}$, respectively (see Table 2). All of the abovementioned results clearly suggested that the $\mathrm{MS} @ \mathrm{NH}_{2} @ \mathrm{COOH} @ \mathrm{DOX} @ \mathrm{x}$ system had a significant killing effect on A549 cells and therefore has great potential for application in the drug delivery field.

\subsection{Loading and release of $D O X$}

\subsubsection{Loading rates of different $D O X$ samples}

Table 3 compares the DOX-loading capacities of $\mathrm{MS} @ \mathrm{x}$ and $\mathrm{MS} @ \mathrm{NH}_{2} @ \mathrm{COOH} @ \mathrm{x}$. Loading capacity is defined as the amount of loaded DOX divided by the amount of DOX used in the loading experiment. The loading of DOX on MS was achieved based on the principle of adsorption and electrostatic interaction, and this result was in agreement with earlier reports. ${ }^{53,54}$ Notably, due to the increase in active sites on the modified materials, the loading capacity 


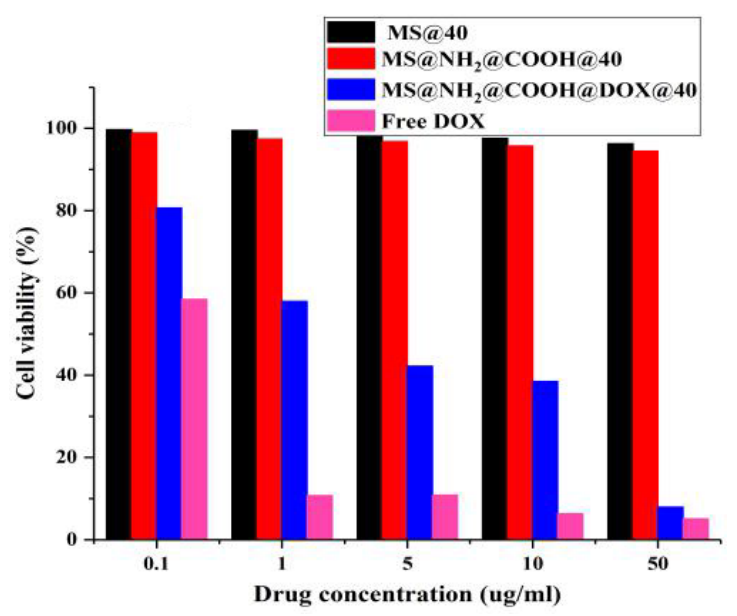

(a)

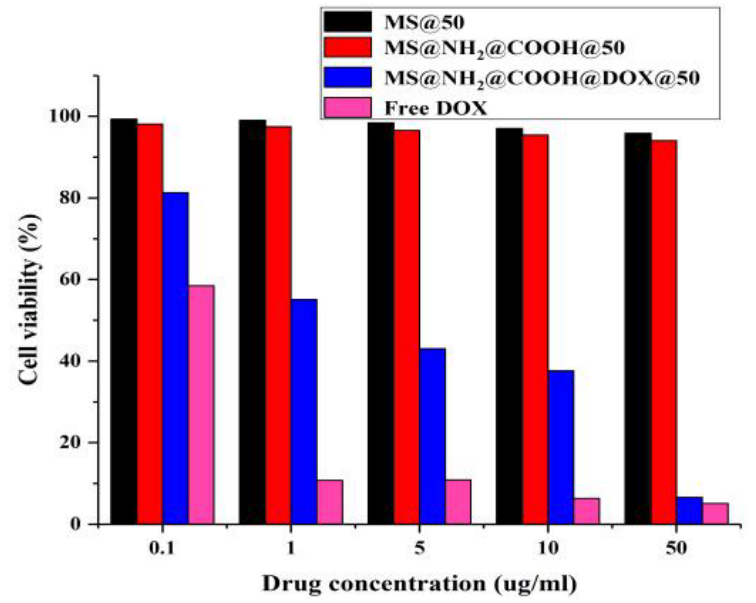

(b)

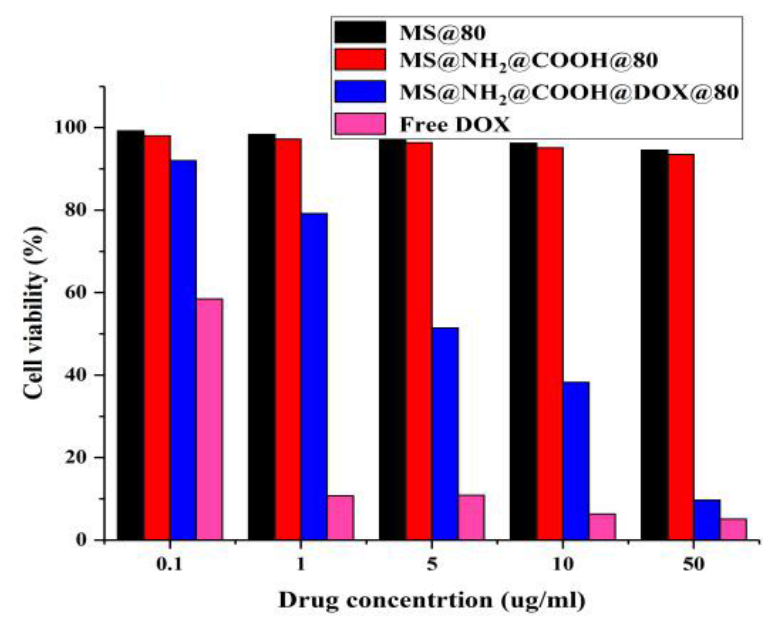

(c)

Fig. 7. The cytotoxicity of $\mathrm{MS} @ \mathrm{x}, \mathrm{MS} @ \mathrm{NH}_{2} @ \mathrm{COOH} @ \mathrm{x}, \mathrm{MS}_{\mathrm{N} H} @ \mathrm{COOH} @ \mathrm{DOX} @ \mathrm{x}$ and free DOX.

of $\mathrm{MS} @ \mathrm{NH}_{2} @ \mathrm{COOH} @ \mathrm{x}$ in this study is higher than that of MS@x. The drug-loading property of MS nanocomposites was found to be $4.85 \%, 5.28 \%$ and $4.93 \%$ for MS@x, but $31.70 \%, 25.66 \%$ and $20.40 \%$ for $\mathrm{MS} @ \mathrm{NH}_{2} @ \mathrm{COOH} @ \mathrm{x}$, respectively. Thus, $\mathrm{MS} @ \mathrm{NH}_{2} @ \mathrm{COOH} @ \mathrm{x}$ possesses a high drug-loading capacity and could induce a high rate of cytotoxic effects on cancer cells. ${ }^{55,56}$ Moreover, the loading

Table 2. $\quad \mathrm{IC}_{50}$ values of $\mathrm{MS} @ \mathrm{NH}_{2} @ \mathrm{COOH} @ \mathrm{DOX} @ \mathrm{x}$ and free DOX.

\begin{tabular}{lc}
\hline Sample & $\mathrm{IC}_{50}(\mu \mathrm{g} / \mathrm{mL})$ \\
\hline $\mathrm{MS} @ \mathrm{NH}_{2} @ \mathrm{COOH} @ D O X @ 40$ & 3.125 \\
$\mathrm{MS} @ \mathrm{NH}_{2} @ \mathrm{COOH} @ D O X @ 50$ & 2.901 \\
$\mathrm{MS} @ \mathrm{NH}_{2} @ \mathrm{COOH} @ D O X @ 80$ & 5.315 \\
Free DOX & 0.143 \\
\hline
\end{tabular}

capacity and loading time of $\mathrm{MS} @ \mathrm{NH}_{2} @ \mathrm{COOH}$ have significant advantages over previously reported drug delivery systems (see Table 4 ). ${ }^{35-38}$

\subsubsection{Release of DOX}

Figures 8(a) and 8(b) show the cumulative release curves of MS@40, MS@50 and MS@80 directly loaded onto DOX with $\mathrm{pH} 7.4$ and 5.5 buffer solutions. DOX released from MS@x reached 29.58\%, $13.21 \%$ and $17.97 \%$ at $40^{\circ} \mathrm{C}, 50^{\circ} \mathrm{C}$ and $80^{\circ} \mathrm{C}$, respectively, in a neutral environment. MS@x released much more DOX in an acidic environment than it did in a neutral environment. Figures 8(c) and $8(\mathrm{~d})$ show the cumulative release curve of $\mathrm{MS} @ \mathrm{NH}_{2} @ \mathrm{COOH} @ \mathrm{DOX} @ \mathrm{x}$ with $\mathrm{pH} 7.4$ and 5.5 buffer solutions, respectively. At a low $\mathrm{pH}$, the 
Table 3. DOX-loading capacities of $\mathrm{MS} @ \mathrm{x}$ and $\mathrm{MS} @ \mathrm{NH}_{2} @ \mathrm{COOH} @ \mathrm{x}$ ( $x$ represents temperatures of $40^{\circ} \mathrm{C}, 50^{\circ} \mathrm{C}$ and $\left.80^{\circ} \mathrm{C}\right)$.

\begin{tabular}{lcccc}
\hline Sample & $\begin{array}{c}\text { Specific surface area } \\
(\mathrm{SBET})\left(\mathrm{m}^{2} \mathrm{~g}^{-1}\right)\end{array}$ & $\begin{array}{c}\text { Pore volume } \\
(\mathrm{Vp})\left(\mathrm{cm}^{3} \mathrm{~g}^{-1}\right)\end{array}$ & $\begin{array}{c}\text { BJH adsorption } \\
\text { pore diameter }(\mathrm{nm})\end{array}$ & $\begin{array}{c}\text { Loading } \\
\text { rate }(\%) 24 \mathrm{~h}\end{array}$ \\
\hline $\mathrm{MS}$ (40 & 987.79 & 0.75 & 2.42 & 4.85 \\
$\mathrm{MS} @ \mathrm{NH}_{2} @ 40$ & 569.58 & 0.034 & 1.77 & - \\
$\mathrm{MS} @ \mathrm{NH}_{2} @ \mathrm{COOH} 40$ & 32.56 & 0.004 & 1.74 & 31.70 \\
$\mathrm{MS} @ 50$ & 673.43 & 0.41 & 2.15 & 5.28 \\
$\mathrm{MS} @ \mathrm{NH}_{2} @ 50$ & 443.56 & 0.32 & 1.77 & - \\
$\mathrm{MS} @ \mathrm{NH}_{2} @ \mathrm{COOH} 50$ & 31.62 & 0.004 & 1.71 & 4.93 \\
$\mathrm{MS} @ 80$ & 915.27 & 0.65 & 2.14 & - \\
$\mathrm{MS} @ \mathrm{NH}_{2} @ 80$ & 549.817 & 0.134 & 1.74 & 20.40 \\
$\mathrm{MS} @ \mathrm{NH}_{2} @ \mathrm{COOH} @ 80$ & 37.62 & 0.012 & 1.74 & \\
\hline
\end{tabular}

Table 4. The comparison of loading capacity and loading time.

\begin{tabular}{lccc}
\hline Sample & $\begin{array}{c}\text { Loading } \\
\text { capacity (\%) }\end{array}$ & $\begin{array}{c}\text { Loading } \\
\text { time (h) }\end{array}$ & Reference \\
\hline BNNS-FA & 2.63 & 24 & 34 \\
HMSN & - & 72 & 35 \\
Al-MCM-41 & 13.19 & 24 & 37 \\
MCM & 20 & 48 & 38 \\
MS@NH $@$ COOH & 31.70 & 24 & This article \\
\hline
\end{tabular}

amount of DOX released from $\mathrm{MS} @ \mathrm{NH}_{2} @ \mathrm{COOH} @ \mathrm{x}$ can reach $13.65 \%, 12.25 \%$ and $14.45 \%$, whereas $\mathrm{MS} @ \mathrm{NH}_{2} @ \mathrm{COOH} @ \mathrm{DOX} @ \mathrm{x}$ released only 6.00\%, $6.74 \%$ and $5.53 \%$ at a high $\mathrm{pH}$ at the corresponding temperature, which suggests that acidic conditions accelerated the release of DOX. Figures 8(e) and $8(\mathrm{f})$ show the DOX release profiles from MS@x and $\mathrm{MS} @ \mathrm{NH}_{2} @ \mathrm{COOH} @ \mathrm{x}$ under a physiological environment and weak acid conditions. The DOX showed a $\mathrm{pH}$-sensitive and sustained drug release from the modified silica nanorattle up to two days, with a more rapid drug release rate at $\mathrm{pH} 5.5$ (close to the $\mathrm{pH}$ in lysosomes) than at $\mathrm{pH} 7.4$ (the $\mathrm{pH}$ of blood plasma).

As the chart shows, the drug released about $29.58 \%, 13.30 \%$ and $19.97 \%$ from unmodified nanomaterials at $\mathrm{pH} 7.4$, but released only $6.00 \%$, $6.74 \%$ and $5.53 \%$ from organic modified nanomaterials at the same $\mathrm{pH}$. Homoplastically, the drug release amount reached $60.34 \%, 51.52 \%$ and $58.36 \%$ from unmodified nanomaterials at $\mathrm{pH} 5.5$, but released only $13.65 \%, 12.25 \%$ and $14.45 \%$ from organic modified nanomaterials at the same $\mathrm{pH}$, indicating that organic functionalization can control the drug release and achieve sustained drug release.
The pH-sensitive drug release profile is consistent with previous reports of DOX release from MS nanomaterials, ${ }^{57}$ which can be attributed to the adsorption and electrostatic interaction between the silica nanoparticles and drug molecules under different $\mathrm{pH}$ values.

The organic groups were divided into two parts and grafted onto the inner wall of mesoporous silica. Therefore, two parts of DOX were adsorbed, i.e., one part was adsorbed onto the inner pore wall through the "hydrogen effect" between amine and carboxylic groups as well as via ionic interaction, whereas the other part was adsorbed onto the surface of MS through the ionic interaction between amine and carboxylic groups as well as the "molecular switch effect" of the organic groups. Thus, on the basis of this finding, this study proposed an ionic interaction occurring between the amine groups of DOX and the carboxylic groups of the silica surface and pore wall, which weakens the "hydrogen bond effect" due to "steric effects." Moreover, the pore outlets appear in a "half open and half closed state" at high $\mathrm{pH}$ (7.4). Thus, the release of DOX was also inhibited [Figs. 8(a), 8(c) and $8(\mathrm{e})]$. At a low pH (5.5), the Coulombic repulsion among ammonium groups ("closed" state) will be weakened due to the ionic interaction between amine and carboxylic groups. Consequently, the gate opens partway and a certain amount of DOX is released. In addition, the modified groups have the effect of encapsulation and ionic interaction with the drug, thus allowing sustained release of the drug at both $\mathrm{pH}$ values (7.4 and 5.5).

According to the above experimental data analysis, the $\mathrm{MS} @ \mathrm{NH}_{2} @ \mathrm{COOH} @ \mathrm{x}$ drug delivery system not only exhibited excellent $\mathrm{pH}$-responsive release 
S. Wang et al.

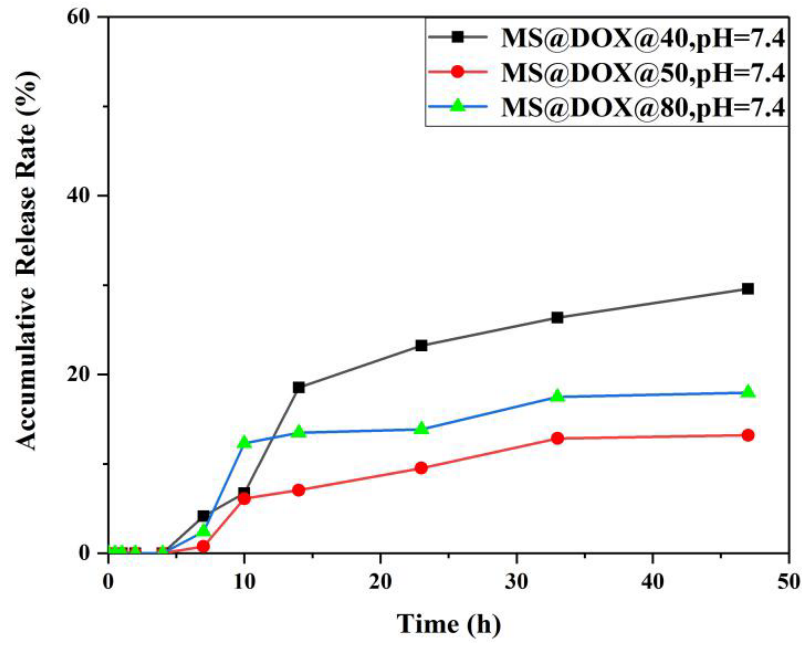

(a)

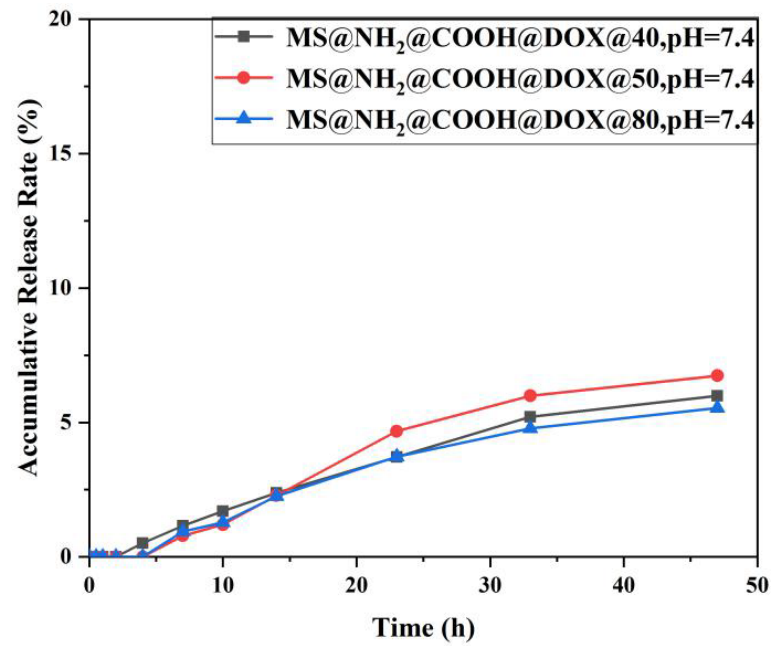

(c)

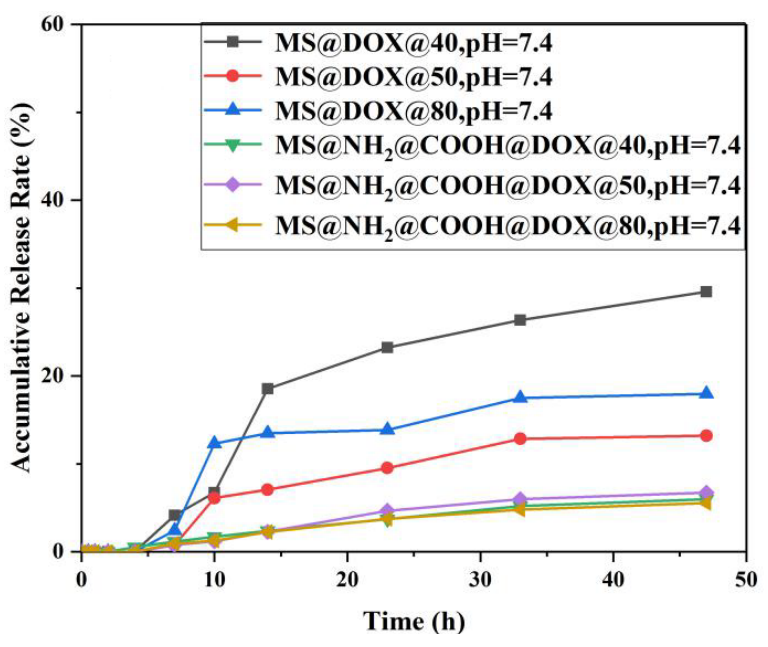

(e)

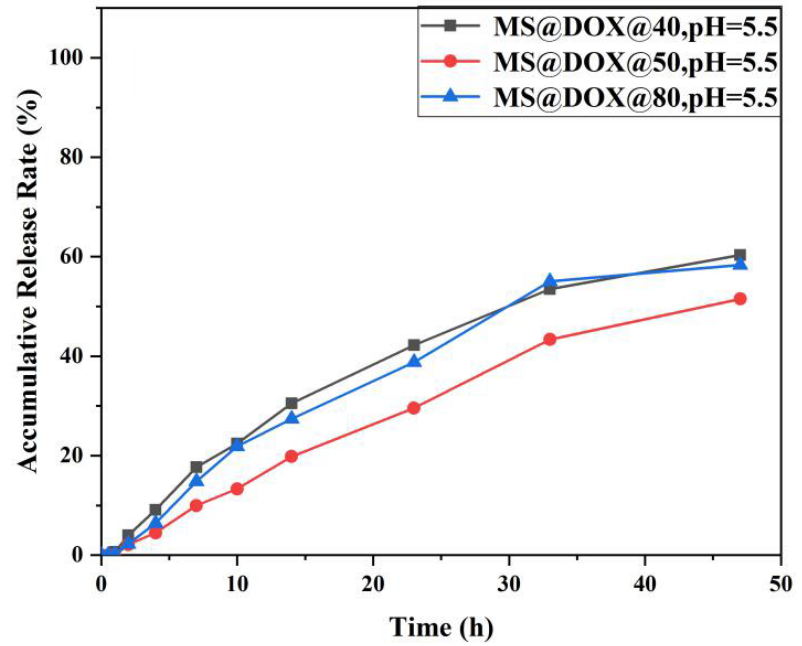

(b)

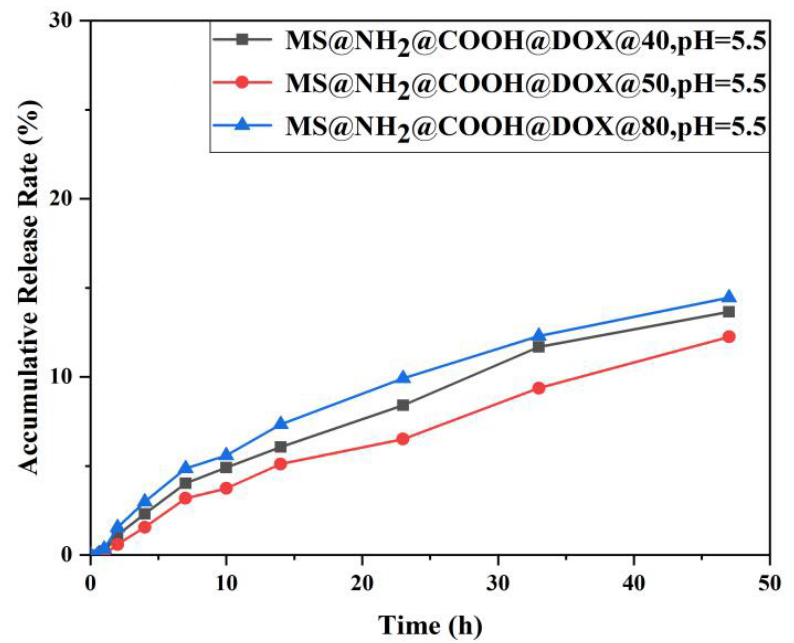

(d)

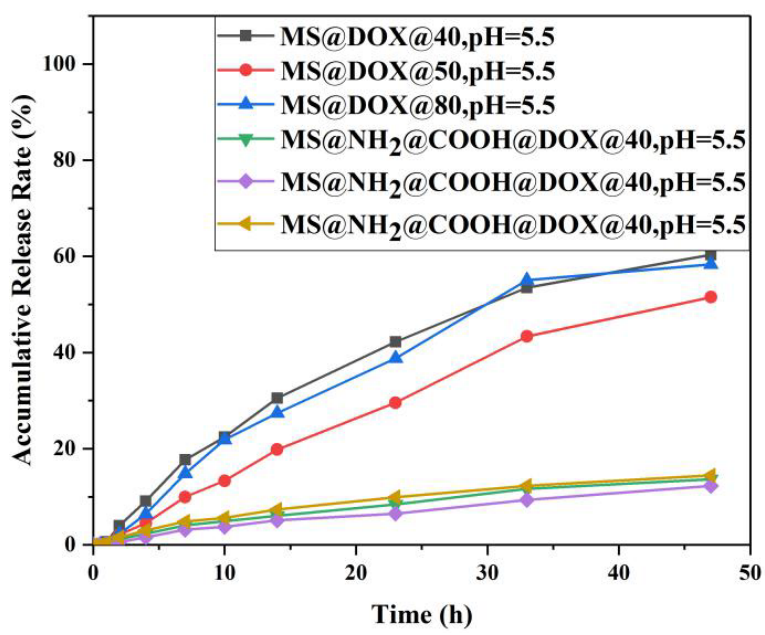

(f)

Fig. 8. DOX release rates of the MS@DOX@x and MS@NH $\mathrm{N}_{2} @ \mathrm{COOH} @ D O X @ x$ samples with pH 7.4 and 5.5 buffer solutions. 
behavior, but also sustained release compared with a traditional drug delivery system.

\section{Conclusions}

In summary, we successfully synthesized amino and carboxyl modified MS nanoparticles. The change in temperature does not influence the morphology of the materials. Moreover, particle size exhibits a uniform increase. A simple method for preparing pH-responsive (organic groups) delivery systems has been described. Characterization analyses show that pore diameter, pore volume and specific surface area decrease after organic functionalization. Furthermore, organic groups have been grafted around the pore outlet and inner pore wall; these modified groups play the role of a "molecular gate." The results of systematic investigation and release experiment analysis show that the loading rate can reach $31.70 \%$. The pore size had no influence on the quality of the adsorbed drug. DOX in all the carriers is released slowly at a high $\mathrm{pH}(7.4)$, but most of the DOX was released from the mesoporous surface and inner pore wall at a low $\mathrm{pH}$ (5.5). Through the results of a cell cytotoxicity assay on A549 cells, we found that DOX-loaded nanomaterials have a good killing effect. These results indicated that $\mathrm{MS} @ \mathrm{NH}_{2} @ \mathrm{COOH} @ D O X @ \mathrm{x}$ served as an effective drug delivery vehicle and may possess great potential to control drug release.

\section{Funding}

We acknowledge financial support from the Guizhou Provincial Science and Technology Department joint fund project (QKHLH[2017]7289).

\section{Acknowledgments}

We thank Guizhou university test center for characterization of TEM and SEM of materials, and all those who contributed to the study but did not meet the authorship criteria. We thank Enpaper (www. Enpaper.com) for its linguistic assistance during the preparation of this paper.

\section{References}

1. X. Zhao et al., Part. Part. Syst. Charact. 32, 529 (2015).
2. X. Zhao et al., Colloids Surf. B, Biointerfaces 130, 1 (2015).

3. X. Zhao et al., Small 11, 4221 (2015).

4. G. Wang et al., J. Solid State Chem. 182, 1649 (2009).

5. M. Moritz, Appl. Surf. Sci. 283, 537 (2013).

6. T. Asefa and M. J. Maclachlan, Nature 402, 867 (1999).

7. S. Inagaki et al., J. Am. Chem. Soc. 121, 9611 (1999).

8. B. J. Melde et al., Chem. Mater. 11, 3302 (1999).

9. P. Yang et al., Chem. Mater. 11, 2813 (1999).

10. Y. Zhang et al., Appl. Surf. Sci. 276, 769 (2013).

11. Z. Zhang et al., ACS Nano 7, 8455 (2013).

12. M. Frasconi et al., J. Am. Chem. Soc. 135, 11603 (2013).

13. S. Inagaki et al., Nature 416, 304 (2002).

14. F. Hoffmann et al., Angew. Chem. Int. Ed. Engl. 45, 3216 (2006).

15. C. T. Kresge et al., Nature 359, 710 (1992).

16. I. I. Slowing et al., Adv. Drug Deliv. Rev. 60, 1278 (2008).

17. Q. J. He et al., Biomaterials 31, 3335 (2010).

18. Q. J. He et al., Biomaterials 31, 1085 (2010).

19. M. Zhu et al., Biomaterials 32, 1986 (2011).

20. Q. He et al., Biomaterials 32, 7711 (2011).

21. M. Vallet-Regi et al., Chem. Mater. 13, 308 (2001).

22. F. Qu et al., Chemphyschem: A Eur. J. Chem. Phys. Phys. Chem. 7, 400 (2006).

23. Y. Yang et al., Chem. Commun. 47, 12167 (2011).

24. C. W. Wu and Y. Yamauchi, J. Mater. Chem. 22, 1251 (2011).

25. W. Zeng et al., Mater. Res. Bull. 40, 766 (2005).

26. F. Chen et al., ACS Nano 7, 9027 (2013).

27. N. A. Alyoshina and E. V. Parfenyuk, J. Solid State Chem. 205, 211 (2013).

28. F. Xie et al., Microporous Mesoporous Mater. 266, 177 (2018).

29. M. Etienne, B. Lebeau and A. Walcarius, New J. Chem. 26, 384 (2002).

30. T. Huang and W. Tu, Appl. Surf. Sci. 255, 7672 (2009).

31. A. Datt, I. El-Maazawi and S. C. Larsen, J. Phys. Chem. C 116, 18358 (2012).

32. L. Gao et al., Mater. Chem. Phys. 135, 786 (2012).

33. R. Xing et al., Colloids Surf. A. Physicochem. Eng. Asp. 403, 7 (2012).

34. S. Feng et al., Int. J. Nanomed. 11, 4573 (2016).

35. C. Adhikari et al., J. Drug Deliv. Sci. Technol. 45, 303 (2018).

36. H. Meng et al., ACS Nano 4, 4539 (2010).

37. I. S. Carino et al., Drug Deliv. 14, 491 (2007).

38. P. Botella, A. Corma and M. Quesada, J. Mater. Chem. 22, 6394 (2012). 
S. Wang et al.

39. R. Casasús et al., J. Am. Chem. Soc. 126, 8612 (2004).

40. W. Stöber, A. Fink and E. Bohn, J. Colloid Interf. Sci. 26, 62 (1968).

41. Z. S. Eren et al., Microporous Mesoporous Mater. 235, 211 (2016).

42. X. Guo et al., Langmuir 26, 702 (2010).

43. C. Wu et al., Int. J. Pharm. 403, 162 (2011).

44. P. Visuvamithiran et al., Catal. Sci. Technol. 3, 2340 (2013).

45. M. Kruk and M. Jaroniec, Chem. Mater. 13, 3169 (2001).

46. C. J. Tsou, Y. Hung and C. Y. Mou, Microporous Mesoporous Mater. 190, 181 (2014).

47. K. Lee, D. Lee and H. Lee, Korean J. Chem. Eng. 27, 1333 (2010).
48. H. Blas et al., Macromolecules 44, 2577 (2011).

49. H. Lin et al., Langmuir 25, 10159 (2009).

50. C. P. Jaroniec et al., J. Phys. Chem. B. 102, 5503 (1998).

51. C. Airoldi and V. V. Oliveira, Mater. Res. Bull. 59, 214 (2014).

52. M. M. Ayad et al., Microporous Mesoporous Mater. 229, 166 (2016).

53. M. Cetin et al., Pharm. Dev. Technol. 18, 570 (2013).

54. L. Xing, H. Zheng and Y. Cao, Adv. Mater. 24, 6433 (2012).

55. K. Wu et al., J. Mater. Chem. B. 50, 5658 (2017).

56. R. Vivek et al., Int. J. Biol. Macromol. 65, 289 (2014).

57. Y. Chen et al., Adv. Funct. Mater. 21, 270 (2011). 